\title{
Divergence and estimates of genetic parameters in Crambe abyssinica: an oilseed plant for industrial uses ${ }^{1}$
}

\author{
Rebeca Lourenço de Oliveira ${ }^{2 *}$, Luiz Antônio dos Santos Dias², Thais Roseli Corrêa ${ }^{2}$, \\ Pedro Henrique Silva Ferreira ${ }^{2}$, Martha Freire da Silva ${ }^{2}$
}

10.1590/0034-737X201865060005

\begin{abstract}
Crambe's breeding is still incipient, with few cultivars of interest. The aims of the present study were: i) to evaluate the divergence between 10 genotypes of crambe, through morphoagronomic and quality traits, using multivariate analyses; and ii) to estimate genetic parameters related to these traits. The trial was conducted in a greenhouse, and the experimental data were submitted to multivariate analysis and genetic evaluation. The genotypes differed significantly among them for plant height $(\mathrm{PH})$, stem diameter $(\mathrm{SD})$, number of branches per plant $(\mathrm{NB})$, height of the first productive branch (HPB), mass of 1000 grains (M1000), grain yield (YIELD) and oil productivity (OIL). The experimental coefficient of variation revealed good precision (4.29 to 13.81\%). The averages of YIELD (1936.94 kg/ha) and OIL (660.10 kg/ha) were high. The traits presented high estimates of broad-sense heritability on a mean genotype basis $\left(\mathrm{h}^{2}>73.65\right)$. The cluster analysis revealed five clusters of genotypes. YIELD showed the greatest contribution (22.31\%) to the diversity among the genotypes, followed by HPB, NB and SD. Genotypes 2 and 4 can be used as parents at future crosses, as they are promising in obtaining segregant populations.
\end{abstract}

Keywords: biofuels; plant breeding; oilseed plant; Brassicaceae.

\section{RESUMO}

\section{Divergência e estimativas de parâmetros genéticos em Crambe abyssinica: uma planta oleaginosa para usos industriais}

O melhoramento do crambe ainda é incipiente, com poucas cultivares de interesse. Os objetivos do presente trabalho foram: i) avaliar a divergência entre 10 genótipos de crambe, por meio de características morfoagronômicas e de qualidade, utilizando análises multivariadas e; ii) estimar parâmetros genéticos relativos a essas características. O experimento foi conduzido em casa de vegetação, e os dados obtidos foram submetidos a análises multivariadas e de avaliação genética. Os genótipos diferiram significativamente entre si quanto a altura de planta (ALT), diâmetro do caule (DC), número de ramos por planta (NR), altura do primeiro ramo produtivo (ARP), massa de 1000 grãos (M1000), produtividade de grãos (PROD) e de óleo (PO). O coeficiente de variação revelou boa precisão experimental (4,29 a 13,81\%). As médias de PROD (1936,94 kg/ha) e de PO (660,10 kg/ha) foram elevadas. As características apresentaram altas estimativas de herdabilidade em nível de médias de progênies $\left(\mathrm{h}^{2}>73,65\right)$. A análise de cluster revelou cinco grupos de genótipos. PROD foi a característica com maior contribuição $(22,31 \%)$ para a diversidade entre os genótipos, seguida por ARP, NR e DC. Os genótipos 2 e 4 podem ser utilizados como genitores em cruzamentos futuros, pois são promissores na obtenção de populações segregantes.

Palavras-chave: biocombustíveis; melhoramento de plantas; oleaginosas; Brassicaceae.

\footnotetext{
Submitted on March 26 th, 2018 and accepted on November $7^{\text {th }}, 2018$

${ }^{1}$ This work is part of the first author's master thesis

${ }^{2}$ Universidade Federal de Viçosa, Departamento de Fitotecnia, Viçosa, Minas Gerais, Brazil. rebecalourencoo@gmail.com; lasdias@ufv.br; thaisroselicorrea@hotmail.com; pedrohsferreira29@gmail.com; marthafreire86@hotmail.com

"Corresponding author: rebecalourencoo@gmail.com
} 


\section{INTRODUCTION}

Crambe (Crambe abyssinica Hochst) is a hexaploid $(2 \mathrm{n}=6 \mathrm{x}=90)$ species and an important Brassicaceae oilseed (Du et al., 2014). This family covers about 350 genus and 3200 species. Other species of this family, such as canola (Brassica napus) and various types of mustard (B. juncea, B. campas, B. alba, B. nigra) are similar to crambe (Desai et al., 2004). The genus Crambe is composed of more than 30 species, being $C$. abyssinica the only cultivated (Desai et al., 2004).

In the past, crambe was used as fodder for soil cover. Currently, the plant presents high potential for oil production (Carlsson, 2009). The oil extracted from crambe seeds has the potential to be used in the manufacture of plastic films, adhesives, nylon, thermal insulation, corrosion inhibitors, synthetic rubber and industrial lubricant (Carlson et al., 1996; Falasca et al., 2010). The crambe seeds oil can be used advantageously for the production of biodiesel (Tavares et al., 2017), as it has a higher resistance to degradation and oxidation (Lalas et al., 2012). However, when refined, this same oil can be used in the production of cosmetics (Falasca et al., 2010) and waxes (Zhu et al., 2016). In addition, crambe bran, a byproduct of oil extraction, presents excellent nutritional quality, with up to $45 \%$ crude protein, and can be used as a protein supplement in ruminant feed (Carlson et al., 1996).

The interest in the crambe's crop is increasing and its breeding is in progress. In Brazil, there is already a cultivar adapted to its conditions, the 'FMS Brilhante', obtained by the MS Foundation through the lineages from Mexico in the 1990s. In other countries, such as the USA, there are other cultivars such as Meyer, Indy, Bellan, Prophet and Bellinzian. The main objectives for the breeding in this crop are: increase of grain yield, oil content, erucic acid content in oil, lower seed dormancy, among others (Knights, 2002).

Due to the high productivity, oil and erucic acid content and the possibility of using this crop in the autumn-winter season for oil production and cycle breakdown of several pathogens, researches with crambe has been intensified in the last years. However, the information is still incipient of for this crop, lacking more studies in the genetic improvement.

In breeding programs, studies on genetic divergence to identify potential crossings and to know the genetic basis of genotypes are extremely important. However, efficient methods of quantifying genetic diversity assist in selection success of the best individuals, maximizing gain and the efficiency in development of new cultivars (Farias Neto et al., 2008). The multivariate analysis in the quantification of genetic divergence is an advantageous method, since it allows identifying sources of variability evaluates the importance of each measured trait and knows the heterotic hybrid combinations, even before the crossings (Sávio et al., 2008).

Another important analysis in breeding programs is the estimation of genetic parameters, since they allow to identify the nature of gene action involved in the control of quantitative traits, as well as to evaluate the efficiency of breeding strategies to obtain genetic gains (Cruz et al., 2014). One of the most important genetic parameters is the heritability coefficient, which measures the proportion of genetic variation in relation to the total variation. However, this coefficient may suffer variations owing to changes in environmental conditions (Falconer \& Mackay, 1996).

In this context, the aims of this work were: i) to evaluate the genetic divergence among 10 crambe genotypes, through morphoagronomic and quality traits, using multivariate analyses, and ii) estimate the genetic parameters related to these traits.

\section{MATERIAL AND METHODS}

\section{Experimental design and evaluated traits}

The trial was conducted in a greenhouse of the experimental field “Diogo Alves de Mello", (2045' S, 42 $52^{\circ}$ ' W and $650 \mathrm{~m}$ asl), at the Univesidade Federal de Viçosa (UFV), in Viçosa-MG, Brazil, from April to July 2016. The experimental design used was a randomized complete block with 10 treatments (genotypes), four replications, being each replication with 5 plants totaling 200 experimental units. The seeds, provided by the Mato Grosso do Sul Foundation (MS Foundation), were treated with the fungicide and planted at a depth of approximately $3 \mathrm{~cm}$, using three seeds per pot. Twenty days after sowing, thinning was performed to conduct one plant per pot.

The following traits were evaluated:

- Plant height (PH, in cm), measured with a measuring tape, as the distance between the soil surface and the apex of the plant;

- Stem diameter (SD, in mm). Measurements performed close to the ground using a pachymeter;

- Number of branches per plant (NB), obtained by counting the branches in each plant;

- Height of the first productive branch (HPB, in $\mathrm{cm}$ ), corresponding to the measurement of the distance between the soil surface to the first productive branch;

- Mass of 1000 grains (M1000, in g), measured by weighing eight sub-samples of 100 grains per plant. The samples were weighed, correcting the degree of humidity to $9 \%$. M1000 was determined according to the Rules for Seed Analysis (Brasil, 2009); 
- Grain yield (YIELD, in $\mathrm{kg} / \mathrm{ha}$ ), evaluated through the harvest of each plant, and the value obtained being transformed to $\mathrm{kg} / \mathrm{ha}$, with humidity correction to $9 \%$;

- Oil content (OIL, in \%), measured using the Soxhlet extractor. For this, $10 \mathrm{~g}$ of crushed seeds were used, which were placed in pre-weighed filter paper cartridges, recording the combined weight. The samples were taken to Soxhlet using hexane extractor at $80^{\circ} \mathrm{C}$ and subsequently at $110^{\circ} \mathrm{C}$ for 4 hours. After this process, the samples were placed in a drying oven at $70{ }^{\circ} \mathrm{C}$ for 24 hours. After this time, the cartridges were weighed again to determine the oil content based on the dry mass. This evaluation was realized at the Biotechnology Laboratory of the Department of Fitotecnia (Plant Science) at UFV. The oil content was estimated using the formula:

$O I L=\frac{C B E-C A E}{C B E-C W B} * 100$

wherein:

CBE: cartridge with sample before extraction

CAE: cartridge with sample after extraction

CWB: cartridge without samples before extraction

- Oil productivity (OP in $\mathrm{kg} / \mathrm{ha}$ ), obtained by the expression:

$O P=\frac{(Y E L D * O I L)}{100}$

\section{Statistical analysis}

The data were performed to univariate analysis of variance (ANOVA) to evaluate the existence of genetic variability among the genotypes, according to the statistical model: $Y_{i j}=\mu+g_{i}+b_{j}+\varepsilon_{i j}$ wherein:

$Y_{i j}$ : value observed for a trait, relative to the i-th genotype, in the j-th block;

$\mu$ : general mean;

$g_{i}$ : effect associated with the $\mathrm{i}$-th genotype, being $\mathrm{i}=$ $1,2, \ldots, \mathrm{g}$;

$b_{j}$ : effect associated with the $\mathrm{j}$-th block, being $\mathrm{j}=1,2, \ldots, \mathrm{b}$; $\varepsilon_{i j}:$ effect of experimental error.

The significance of the mean squares was tested by the F test $(\mathrm{p}<0.01)$, the means were compared by the Scott-Knott test $(\mathrm{p}<0.05)$ and, from ANOVA, the genetic parameters were estimated for each trait, according to Cruz et al. (2012):

- Genetic variation coefficient (\%): $C V_{g}=\frac{\sqrt{\hat{\sigma}_{g}^{2}}}{\mu} * 100$ - b quotient $(\mathrm{CVg} / \mathrm{CVe}$ ratio $): \sqrt{\frac{\hat{\sigma}_{\mathrm{g}}^{2}}{\hat{\sigma}_{e}^{2}}}$
- Mean genotypic variance:

- Mean phenotypic variance: $\hat{\sigma}_{p}^{2}=\frac{M S g}{r}$

- Mean environmental variance: $\hat{\sigma}_{e}^{2}=\frac{M S e}{r}$

- Broad sense heritability on a mean genotype basis:

$h_{m}^{2}=\frac{\hat{\sigma}_{g}^{2}}{\hat{\sigma}_{p}^{2}} * 100$

The multivariate analysis for the quantification of divergence was performed using the generalized Mahalanobis distance $\left(\mathrm{D}^{2}\right)$ between genotypes, where the distance between the pair of genotypes i and i' were defined by the expression (Cruz et al., 2012):

$D_{i i}^{2}=\delta_{i i} \psi^{-1} \delta_{i i}$

$D_{i i}^{2}$ : generalized Mahalanobis distance between genotypes $\mathrm{i}$ and i', being $\mathrm{i}=1,2, \ldots, \mathrm{g}$

$\delta_{i i}=\left[d_{1} d_{2} \ldots d_{n}\right]$ being $D_{n}=Y_{i j}-Y_{i^{\prime} j}$ for genotypes i and i' and $d$ is the difference between the two genotypes means $i$ and i' for each evaluated trait;

$Y_{i j}$ is the mean of the $\mathrm{i}$-th genotype in relation to the $\mathrm{j}$-th trait, being $j=1,2, \ldots, p$

$\psi^{-1}$ inverse of the error variance and covariance matrix.

On the generated Mahalanobis distance matrix was processed clustering analysis by UPGMA (Unweighted Paired Group Method using Arithmetic Averages) algorithm. The relative contribution of the traits to the divergence among genotypes was assessed by the method of Singh (1981), using Mahalanobis generalized distance estimates. All the analytical processing was performed in the Genes software (Cruz, 2013).

\section{RESULTS AND DISCUSSION}

\section{Analysis of variance (ANOVA)}

Univariate ANOVA showed a highly significant ( $\mathrm{p}<$ 0.01 ) effect of the genotypes for all traits evaluated, indicating the presence of genetic variability among them. Besides, the estimated genetic variation confirms the variability among the genotypes, since all were different from zero (Table 1).

In general, the coefficient of experimental variation was low, varying from $4.29 \%$ for YIELD to $13.81 \%$ for HPB, which means that the experiment showed good precision. Lara-Fioreze et al. (2016a), in a study with crambe progenies from individual plant selection, observed higher value of CV for number of branches (> 14.93\%), but still with good experimental precision.

For grain yield (YIELD), the average of the 10 crambe genotypes evaluated was $1936.94 \mathrm{~kg} / \mathrm{ha}$ (Table 1). Genotypes 
2, 3, 5, 6 and 8 highlighted as the most productive of the experiment, with yields higher than $2010 \mathrm{~kg} / \mathrm{ha}$ (Table 2). Viana et al. (2015), evaluated the yield of the cultivar FMS Brilhante at different sowing densities and obtained average values ranging from 1706.12 to $2118.57 \mathrm{~kg} / \mathrm{ha}$. In work with the same cultivar Zoz et al. (2018) obtained grain yield ranging from 1176.7 to $1760.7 \mathrm{~kg} / \mathrm{ha}$. The values presented by both works corroborate the high productive potential of the crambe genotypes evaluated in this experiment.

For oil productivity (OIL), the average of the 10 crambe genotypes evaluated was $660.1 \mathrm{~kg} / \mathrm{ha}$ (Table 1). Genotypes 2, 5, 6 and 8 presented yields higher than $690 \mathrm{~kg} / \mathrm{ha}$ (Table 2). In a study with the cultivar FMS Brilhante, Lunelli et al. (2013) reported an oil productivity of $372 \mathrm{~kg} / \mathrm{ha}$, much lower than that observed in this study, which shows superiority in the genotypes evaluated by our research to oil production. It should be noted that these genotypes are present in the group of higher grain yields. In this way, these materials can be incorporated into future crossover breeding blocks in the genetic improvement of crambe.

The height of the first productive branch (HPB) is an important feature when it comes to mechanized harvesting. The low height makes it difficult to harvest mechanized, which can increase the losses due to the cutting platform working close to the soil (Cortez et al., 2008). It was verified that the average height of the first productive branch of the crambe genotypes evaluated was of $11.20 \mathrm{~cm}$ (Table 1), with featured on genotype 4 , that presented the highest mean for the HPB when compared to the others (Table 2), being possible the use of mechanized harvest for these genotypes, since the crambe crop can use the same machinery harvesting as soybean (Pitol et al., 2010).

Table 1: Summary of ANOVA and estimates of genetic parameters for plant height (PH), stem diameter (SD), height of the first productive branch (HPB), number of branches (NB), mass of 1000 grains (M1000), grain yield (YIELD) and oil productivity (OIL), evaluated in 10 genotypes of crambe

\begin{tabular}{|c|c|c|c|c|c|c|c|c|}
\hline \multirow{2}{*}{ Sources } & \multirow{2}{*}{ df } & \multicolumn{7}{|c|}{ Mean Squares } \\
\hline & & PH & SD & HPB & NB & M1000 & YIELD & OIL \\
\hline Blocks & 3 & - & - & - & - & - & - & - \\
\hline Genotypes & 9 & $169.75^{* *}$ & $3.06 * *$ & $20.58 * *$ & $9.47 * *$ & $1.04 * *$ & $67679.78 * *$ & $7668.85^{* *}$ \\
\hline Error & 27 & 44.72 & 0.35 & 2.39 & 1.38 & 0.24 & 6894.55 & 1341.00 \\
\hline Mean & & 146.34 & 11.05 & 11.20 & 16.89 & 8.90 & 1936.94 & 660.10 \\
\hline $\mathrm{CV}(\%)$ & & 4.57 & 5.39 & 13.81 & 6.95 & 5.46 & 4.29 & 5.55 \\
\hline Minimum & & 130.00 & 8.85 & 6.20 & 13.40 & 7.51 & 1663.48 & 582.35 \\
\hline Maximum & & 162.60 & 12.91 & 18.40 & 21.25 & 10.19 & 2191.28 & 808.58 \\
\hline \multicolumn{9}{|c|}{ Estimates of Genetic Parameters } \\
\hline$C V_{g}(\%)$ & & 3.82 & 7.45 & 19.03 & 8.42 & 5.04 & 6.36 & 6.03 \\
\hline$b^{s}$ & & 0.84 & 1.38 & 1.38 & 1.21 & 0.92 & 1.48 & 1.09 \\
\hline$\sigma_{g}^{2}$ & & 32.26 & 0.68 & 4.55 & 2.02 & 0.20 & 45196.31 & 1581.96 \\
\hline$\sigma_{e}^{2^{8}}$ & & 44.72 & 0.35 & 2.39 & 1.38 & 0.24 & 6894.55 & 1341.00 \\
\hline$h_{m}^{2}(\%)$ & & 73.65 & 88.42 & 88.36 & 85.44 & 77.31 & 89.81 & 82.51 \\
\hline
\end{tabular}

Table 2: Plant height (PH), stem diameter (SD), number of branches (NB), height of the first productive branch (HPB), mass of 1000 grains (M1000), grain yield (YIELD) and oil productivity (OIL) evaluated in 10 genotypes of crambe

\begin{tabular}{lcccrccc}
\hline Genotypes & PH & S D & NB & HPB & M1000 & YIELD & OIL \\
\hline 1 & $158.27 \mathrm{a}$ & $11.58 \mathrm{a}$ & $18.67 \mathrm{a}$ & $12.20 \mathrm{~b}$ & $9.14 \mathrm{a}$ & $1863.68 \mathrm{~b}$ & $625.82 \mathrm{~b}$ \\
2 & $144.97 \mathrm{~b}$ & $11.51 \mathrm{a}$ & $19.95 \mathrm{a}$ & $9.03 \mathrm{~d}$ & $8.44 \mathrm{~b}$ & $2090.50 \mathrm{a}$ & $693.53 \mathrm{a}$ \\
3 & $137.67 \mathrm{~b}$ & $11.56 \mathrm{a}$ & $16.38 \mathrm{~b}$ & $8.59 \mathrm{~d}$ & $8.84 \mathrm{a}$ & $2012.83 \mathrm{a}$ & $661.25 \mathrm{~b}$ \\
4 & $150.87 \mathrm{a}$ & $10.08 \mathrm{~b}$ & $14.40 \mathrm{~b}$ & $15.30 \mathrm{a}$ & $8.96 \mathrm{a}$ & $1840.47 \mathrm{~b}$ & $632.57 \mathrm{~b}$ \\
5 & $140.67 \mathrm{~b}$ & $11.30 \mathrm{a}$ & $15.85 \mathrm{~b}$ & $8.07 \mathrm{~d}$ & $8.75 \mathrm{a}$ & $2064.11 \mathrm{a}$ & $698.87 \mathrm{a}$ \\
6 & $142.60 \mathrm{~b}$ & $11.74 \mathrm{a}$ & $16.84 \mathrm{~b}$ & $10.40 \mathrm{c}$ & $9.16 \mathrm{a}$ & $2075.71 \mathrm{a}$ & $708.89 \mathrm{a}$ \\
7 & $153.80 \mathrm{a}$ & $9.21 \mathrm{c}$ & $16.70 \mathrm{~b}$ & $13.30 \mathrm{~b}$ & $9.06 \mathrm{a}$ & $1822.73 \mathrm{~b}$ & $627.86 \mathrm{~b}$ \\
8 & $147.20 \mathrm{~b}$ & $12.09 \mathrm{a}$ & $15.85 \mathrm{~b}$ & $11.80 \mathrm{~b}$ & $9.86 \mathrm{a}$ & $2039.31 \mathrm{a}$ & $727.30 \mathrm{a}$ \\
9 & $147.20 \mathrm{~b}$ & $10.76 \mathrm{~b}$ & $17.05 \mathrm{~b}$ & $10.87 \mathrm{c}$ & $7.88 \mathrm{~b}$ & $1786.33 \mathrm{~b}$ & $623.12 \mathrm{~b}$ \\
10 & $140.11 \mathrm{~b}$ & $10.70 \mathrm{~b}$ & $17.20 \mathrm{~b}$ & $12.48 \mathrm{~b}$ & $8.89 \mathrm{a}$ & $1773.75 \mathrm{~b}$ & $601.81 \mathrm{~b}$ \\
\hline
\end{tabular}

Means followed by the same letter in the columns belong to the some group by the Scott-Knott test $(\mathrm{P}<0.05)$. 
In study of the crambe's performance in function of plant spacing and density, Freitas et al. (2013) found lower mean values than those observed in our study for the traits plant height $(109 \mathrm{~cm})$, mass of 1000 grains $(7.95 \mathrm{~g})$, number of branches (12.91) and grain yield (783 kg/ha). Laghetti et al. (1995) obtained an average of $7 \mathrm{~g}$ for M1000, while Lara-Fioreze et al. (2016a) observed a mean of $7.72 \mathrm{~g}$ for the same trait studied in the county of Botucatu-SP and $6.93 \mathrm{~g}$ in the county of São Manuel-SP, in 2011, lower values than those found in our research $(8.90 \mathrm{~g})$. The broad variability presented in the crambe genotypes studied is important to be explored at future crosses in breeding programs of the species.

\section{Estimates of genetic parameters}

Estimates of genotypic and environmental variances, as well as the heritability coefficient $\left(h^{2}{ }_{m}\right)$ on a mean genotype basis, the coefficient of genetic variation $(\mathrm{CVg})$ and the b quotient ( $\mathrm{CVg} / \mathrm{CVe}$ ratio) are presented in Table 1. The CVg allows to understand the magnitude of the genetic variability that is present in the population for all the evaluated traits, assisting in the selection of superior genotypes. The $\mathrm{CVg}$ ranged from $3.82 \%$ to $19.03 \%$ for $\mathrm{PH}$ and $\mathrm{HPB}$, respectively. In the case of selection, the $\mathrm{CVg}$ indicates the proportionality of the gain in relation to the mean. The b quotient indicates a situation favorable to the selection of superior genotypes, when it is greater than the unit $(>1)$, since the genetic variation surpasses the environmental one. It is an important parameter to detect the genetic variability in the population (Resende \& Duarte, 2007). The $b$ quotient was higher than the unit for SD, HPB, NB, YIELD and OIL, indicating that the genetic variation was superior to environmental variation and favoring selection for these traits.

The coefficient of heritability is one of the most important parameters in genetic breeding. This coefficient shows how much of genetic variation is inheritable to the generation after selection (Resende, 2015). All the evaluated traits showed high heritability $\left(h_{m}^{2}>73.65 \%\right.$, for $\mathrm{PH}$ ), even when dealing with environment-influenced traits such as grain yield $(89.81 \%)$ and mass of 1000 grain (77.31\%). This can be explained by the fact that these materials have varied origins and, consequently, present variations that allow greater success in the selection of superior genotypes. Lara-Fioreze et al. (2016b) also found high heritability coefficients (> 74.00\%) for the traits studied in 32 superior self-progenies of the FMS Brilhante, except for a mass of 1000 grains estimated to be $56.00 \%$.

\section{Genetic divergence}

The UPGMA dendrogram, based on the Mahalanobis distance matrix, allowed the separation of the genotypes into five clusters. Clusters III, IV and V were formed by only one genotype each (Figure 1). Genotypes 3 and 6 were the most similar pair, with $\mathrm{D}^{2}$ equal to 3.29 and genotypes 2 and 4 showed greater dissimilarity with $\mathrm{D}^{2}$ of 57.52. Cluster I presented the second best average grain yield (2047.99 kg/ha) and the highest productivity of oil ( $699.08 \mathrm{~kg} / \mathrm{ha}$ ) and mass of 1000 grains $(9.15 \mathrm{~g})$, which could be considered a promising group present high average of traits desirable to the culture. Clusters II, composed of three genotypes, obtained moderate grain yield (1812.32 $\mathrm{kg} / \mathrm{ha}$ ) and the lowest oil productivity $(620.75 \mathrm{~kg} / \mathrm{ha})$, as well as smaller stem diameter $(9.99 \mathrm{~mm})$ and number of branches (16.1) (Table 3).

Clusters III, IV and V were represented by only one genotype each, with cluster $\mathrm{V}$ highlighting the highest grain yield (2090.50 kg/ha), besides high oil productivity (693.52 kg/ha) and number of branches (19.95), being also a potential group due to the high observed average. Cluster III had the lowest grain yield (1786.66 kg/ha) and 1000 grain mass $(7.88 \mathrm{~g})$. The IV cluster had the highest plant height $(158.27 \mathrm{~cm})$ and high values for stem diameter $(11.57 \mathrm{~mm})$, height of the first productive branch $(12.2 \mathrm{~cm})$, number of branches (18.67) and 1000 grains mass (9.14 g) (Table 3). These clusters are important for selection of superior genotypes because they show how much of genetic variability is available. In addition, the clustering allows to distinguish genotypes with higher dissimilarity between them that can be used in future crosses. Therefore, the diversity of plant genetic resources allows breeders the opportunity to develop new cultivars with superior characteristics (Govindaraj et al., 2015).

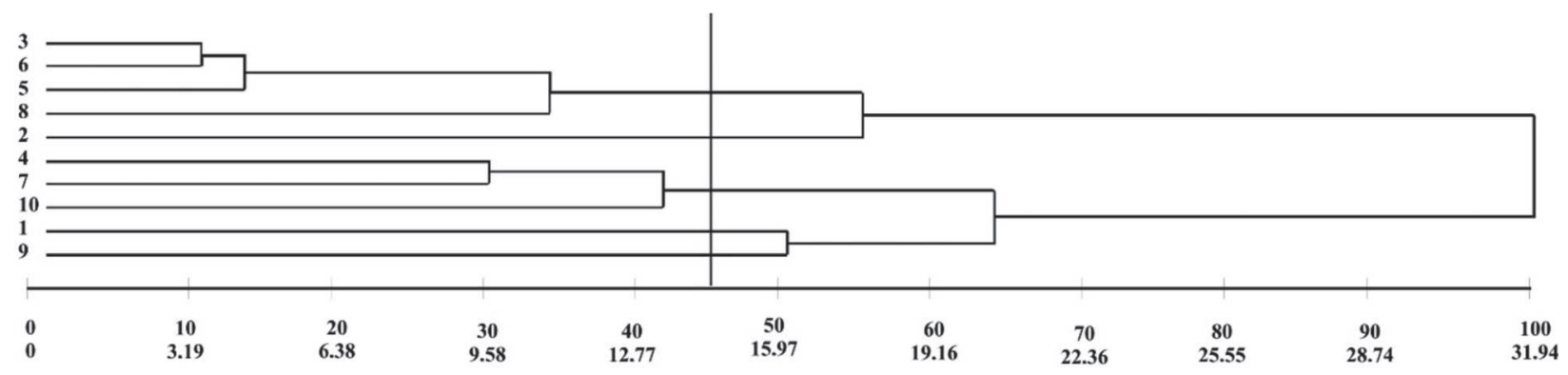

Figure 1: UPGMA dendrogram based on generalized Mahalanobis distance among 10 crambe genotypes. 
Table 3: Plant height (PH), stem diameter (SD), height of the first productive branch (HPB), number of branches (NB), mass of 1000 grains (M1000), grain yield (YIELD) and oil productivity (OIL) of the different clusters of crambe formed from UPGMA

\begin{tabular}{|c|c|c|c|c|c|c|c|}
\hline Clusters & $\begin{array}{l}\text { PH } \\
\text { cm }\end{array}$ & $\begin{array}{l}\text { SD } \\
\text { mm }\end{array}$ & $\begin{array}{c}\text { HPB } \\
\text { cm }\end{array}$ & NB & $\begin{array}{c}\text { M1000 } \\
\mathrm{g}\end{array}$ & $\begin{array}{l}\text { YIELD } \\
\text { kg/ha }\end{array}$ & $\begin{array}{l}\text { OIL } \\
\text { kg/ha }\end{array}$ \\
\hline I & 142.03 & 11.67 & 9.71 & 16.23 & 9.15 & 2047.99 & 699.08 \\
\hline II & 148.26 & 9.99 & 13.69 & 16.10 & 8.97 & 1812.32 & 620.75 \\
\hline III & 147.20 & 10.75 & 10.87 & 17.05 & 7.88 & 1786.33 & 623.12 \\
\hline IV & 158.27 & 11.57 & 12.20 & 18.67 & 9.14 & 1863.68 & 625.82 \\
\hline $\mathrm{V}$ & 144.97 & 11.51 & 9.03 & 19.95 & 8.44 & 2090.50 & 693.52 \\
\hline
\end{tabular}

Table 4: Relative contribution (S.j) of traits to divergence, based on the generalized Mahalanobis distance, in crambe genotypes

\begin{tabular}{lcc}
\hline \multirow{2}{*}{ Traits } & \multicolumn{2}{c}{ Relative contribution } \\
\cline { 2 - 3 } & $\mathbf{S . j}$ & Value $(\%)$ \\
\hline YIELD & 242.39 & 22.31 \\
HPB & 210.10 & $19.3 / 4$ \\
NB & 184.60 & 16.99 \\
SD & 155.02 & 14.27 \\
PH & 116.05 & 10.68 \\
M1000 & 110.98 & 10.21 \\
OIL & 67.43 & 6.21 \\
\hline
\end{tabular}

Although some authors (Papathanasiou et al., 1966; Lessman \& Meier, 1972) report the lack of variability in $C$. abysinica, in the present research, in line with that of Lara-Fiorezze et al. (2016a), revealed wide variability for all the agronomic traits evaluated.

\section{Relative importance of traits}

Regarding the relative contribution of each trait for genetic divergence, based on Sing's method (1981), was verified that YIELD, HPB, NB and SD contributed with $72.90 \%$ (Table 4). It can be affirmed that these traits are important in the genetic divergence study among the genotypes, for presented the most expressive contributions. The oil productivity had the lowest value of S.j (6.21\%), being relatively less important for the evaluation of divergence among the genotypes. The traits that are dispensable in the study of genetic divergence are those that relatively do not vary between the individuals studied or are redundant because they are correlated with other traits (Cruz et al., 2012).

\section{CONCLUSIONS}

Estimates of genetic parameters indicate the presence of genetic variability among the evaluated genotypes.

The traits of grain yield, height of the first productive branch, number of branches and stem diameter were the ones that contributed most to the genetic diversity.
Genotypes 2 and 4 can be used as parents at future crosses, as they are the most promising for obtaining segregating populations.

\section{ACKNOWLEDGMENT}

Thanks are due to CNPq, FAPEMIG, CAPES for resource funding.

\section{REFERENCES}

Brasil (2009) Regras para análise de sementes. Secretaria de Defesa Agropecuária. Brasília, MAPA/ACS. 395p.

Carlsson A (2009) Plant oils as feedstock alternatives to petroleum - A short survey of potential oil crop platforms. Biochimie, 91:665-670.

Carlson KD, Gardener JC, Anderson VL \& Hanzel JJ (1996) Crambe: new crop success. In: Janick J (Ed.) Progress in new crops. Alexandria, ASHS Press. p.306-322.

Cortez JW, Furlani CEA, Silva RP, Lopes A \& Grotta DCC (2008) Densidade de semeadura da soja e profundidade de fertilização. Revista Ceres, 55:396-401.

Cruz CD (2013) GENES - a software package for analysis in experimental statistics and quantitative genetics. Acta Scientiarum Agronomy, 35:271-276.

Cruz CD, Carneiro PSC \& Regazzi AJ (2014) Modelos biométricos aplicados ao melhoramento genético. $3^{\mathrm{a}}$ ed. Viçosa, UFV. 668p.

Cruz CD, Regazi AJ \& Carneiro PCS (2012) Modelos Biométricos Aplicados ao Melhoramento Genético. $4^{\mathrm{a}}$ ed. Viçosa, UFV. 514p.

Desai BB (2004) Seeds handbook: biology, production processing and storage. $2^{\mathrm{a}}$ ed. New York, Marcel Dekker. 787p.

Du XZ, Huang BL, Guan H, Li ZY \& Huang BQ (2014) Production and genetic characterization of interspecific hybrids among Crambe abysinica, Crambe hispanica and Crambe kralikii. Genetics and Molecular Research, 13:6995-7005.

Falasca SL, Flores N, Lama MC, Carballo SM \& Anschau A (2010) Crambe abyssinica: An almost unknown crop with a promissory future to produce biodiesel in Argentina. International Journal of Hydrogen Energy, 35:5808-5812.

Falconer DS \& Mackay TFC (1996) Introduction to Quantitative Genetic. $4^{\mathrm{a}}$ ed. Harlow, Pearson. 480p.

Farias Neto JT, Clement CM \& Resende MD (2008) Estimativas de parâmetros genéticos e ganhos de seleção em progênies de polinização aberta de açaizeiro. Revista Brasileira de Fruticultura, 30:1051-1056.

Freitas ME, Souza LCF, Tanaka KS \& Makino PA (2013) Espaçamento e densidade de plantas no desempenho agronômico da cultura do crambe. Magistra, 25:175-181. 
Govindaraj M, Vetriventhan M \& Srinivasan M (2015) Importance of genetic diversity assessment in crop plants and its recent advances: an overview of its analytical perspectives. Genetics Research International, 2015:431487.

Knights EG (2002) Crambe: A North Dakota case study. Kingston, RIRDC. $25 \mathrm{p}$.

Laghetti G, Piergiovanni AR \& Perrino P (1995) Yield and oil quality in selected lines of Crambe abyssinica (Hochst. ex. R. E. fries) and $C$. hispanica (L.) grown in Italy. Industrial Crops and Products, 04:203-212.

Lalas S, Gortzi O, Athanasiadis V, Dourtoglo E \& Dourtoglou V (2012) Full characterisation of Crambe abyssinica Hochst. Journal of the American Oil Chemists' Society, 89:2253-2258.

Lara-Fioreze ACC, Pivetta LG, Zanotto MD \& Okita CH (2016a) Genetic variation and gain in progenies of crambe. Crop Breeding and Applied Biotechnology, 16:132-140.

Lara-Fioreze ACC, Pivetta LG \& Zanotto MD (2016b) Inbreeding depression in crambe. Pesquisa Agropecuária Tropical, 46:401406.

Lessman KJ \& Meier VD (1972) Agronomic evaluation of crambe as a source of oil. Crop Science, 12:24-227.

Lunelli IE, Deonir S, Araceli CM \& Tiago RBS (2013) Effects of nutritional arrangements of NPK on the yield of grains and crambe oil cultivation. African Journal of Agricultural Resesearch, 08:2048-2052.

Papathanasiou GA (1966) Evaluation of eleven introductions of crambe, Crambe abyssinica Hochst. Agronomy Journal, 58:587589.

Pitol C, Broch DL \& Roscoe R (2010) Tecnologia e Produção: Crambe. Maracaju, Fundação MS. 60p.
Resende MDV \& Duarte JB (2007) Precisão e controle de qualidade em experimentos de avaliação de cultivares. Pesquisa Agropecuária Tropical, 37:182-194.

Resende MDV (2015) Genética quantitativa e de populações. Viçosa, Suprema. 463p.

Sávio FL, Faria PN, Pereira WA, Oliveira AB, Tardin FD, Rodrigues JAS \& Schaffert RE (2008) Divergência genética em híbridos de sorgo cultivados sob diferentes níveis de fósforo, em solução nutritiva. Revista Brasileira de Milho e Sorgo, 07:305-321.

Singh D (1981) The relative importance of characters affecting genetic divergence. The Indian Journal of Genetics and Plant Breeding, 36:237-245.

Tavares GR, Massa TB, Gonçalves JE, Silva C \& Santos WD (2017) Assessment of ultrasound-assisted extraction of crambe seed oil for biodiesel synthesis by in situ interesterification. Renew Energy, 111:659-665.

Viana OH, Santos RF, de Oliveira RC, Secco D, de Souza SNM, Tokura LK, da Silva TRB \& Gurgacz F (2015) Crambe ('Crambe abyssinica'H.) development and productivity under different sowing densities. Australian Journal of Crop Science, 09:690695 .

Zhu LH, Krens F, Smith MA, Li X, Qi W, Van Loo EN, Iven T, Feussner I, Nazarenus TJ, Huai D, Taylor DC, Zhou XR, Green AG, Shockey J, Klasson KT, Mullen RT, Huang B, Dyer JM \& Cahoon EB (2016) Dedicated industrial oilseed crops as metabolic engineering platforms for sustainable industrial feedstock production. Scientific Reports, 06:22181.

Zoz T, Steiner F, Zoz A, Castagnara DD, Witt TW, Zanotto MD \& Auld DL (2018) Effect of row spacing and plant density on grain yield and yield components of Crambe abysinica Hochst. Semina: Ciências Agrárias, 39:393-402. 